\title{
Al-Qur'an Translation in Indonesia: A Case Study of Muhammad Thalib's Qur'an Translation with Reference to Surah Yasin
}

\author{
Fahmi Gunawan ${ }^{1}$, M.R. Nababan ${ }^{2}$, Hanifullah Syukri ${ }^{3}$, Ibnu Burdah ${ }^{4}$ \\ fgunawanp@student.uns.ac.id, amantaradja@yahoo.com, hanifullah@gmail.com. \\ ibnuburdah@gmail.com \\ ${ }^{1}$ Postgraduate Student of Sebelas Maret University Indonesia, Jl. Ir. Sutami No.36, Kentingan, Kec. \\ Jebres, Kota Surakarta, Jawa Tengah 57126 \\ ${ }^{2}$ Faculty of Cultural Science, Sebelas Maret University Indonesia, Jl. Ir. Sutami No.36, Kentingan, Kec. \\ Jebres, Kota Surakarta, Jawa Tengah 57126 \\ ${ }^{3}$ Faculty of Cultural Science, Sebelas Maret University Indonesia, Jl. Ir. Sutami No.36, Kentingan, Kec. \\ Jebres, Kota Surakarta, Jawa Tengah 57126 \\ ${ }^{4}$ Postgraduate Programme, Universitas Islam Negeri Sunan Kalijaga, Indonesia \\ Jl. Laksda Adisucipto, Papringan, Caturtunggal, Kec. Depok, Kabupaten Sleman, Daerah Istimewa \\ Yogyakarta 55281
}

\begin{abstract}
The research on the effect of translation techniques on the quality of Muhammad Talib's Surah Yasin translation is scarce. In that regard, this research aims to explore the impact of the translation techniques on the quality of translation in surah Yasin. To collect data, observation and focused grup discussion were conducted. The findings revealed that the translation techniques applied in Muhammad Talib's were amplification (paraphrasing) technique (27.13\%), established equivalent (25.99\%), explicitation (15.5\%), implicitation $(12.8 \%)$, modulation $(8.52 \%)$, compensation $(3.48 \%)$, transposition $(2.32 \%)$ and discursive creation $(1.55 \%)$. The finding from the analysis also showed that the translation was of average quality. Hence, this study suggests that the use of amplification translation techniques (paraphrase) in addition to extending the translated text, it might also be used to incorporate the discursive idea of the translator into the translated text. This makes the translated text seems to have a certain translator's ideology.
\end{abstract}

Keywords: Surah Yasin, Quranic Translation, Translation Technique and Quality, Muhammad Thalib, Indonesia

\section{Introduction}

The Qur'an as the sacred religious text could be less sacred when it is translated into the target language. This is because the translator's interference is unavoidable in the translation process. Due to the translator's involvement in the source language text, the translation product can be evaluated, even though it is the text of the Qur'an translation. This also means that a translation product can also be evaluated by quality since there is no single translation that is really capable of translating the source language to the target language perfectly. Nababan et al argue that a translation can be of good quality if it is accurate, acceptable, and readable [16]. 
The research on the Qur'an translation by Muhammad Talib is still limited. The discussion is about tarjamah tafsiriyyah or translation with commentary and its translation quality [1], [2], [7], [9], [10], [15], [21]. Indeed, the research on the quality of translations in tarjamah tafsiriyyah only addresses the issue of accuracy and does not address the issue of acceptability and readability in the target language. Similarly, research on the quality of translations only discussess the quality aspects without relating them into the translation techniques. Meanwhile, Molina \& Albir pointed out that the use of translation techniques can affect the quality of translations [14]. These two things can not stand alone and have a relationship between one another. In addition, the research on Surah Yasin is also limited to the issue of how people understand the meaning of Surah Yasin and practice it in daily life [8], [20], [22], [25], Likewise, the issue of linguistic aspects and application technology of translation on Surah Yasin also attracts the attention of experts, such as Mansoori, M., \& Afshari [12], Ridho, Arini \& La Katjong [19] Nurdin \& Puteri [18]. Therefore, none of the studies focused on discussing Surah Yasin in the perspective of translation techniques and translation quality.

To fill the research gap, this article aims to address two topics; they are how the translation techniques used by Muhammad Talib and the influence of translation techniques on the quality of translation in Surah Yasin. Translation of the surah Yasin was chosen because this surah is classified as a very popular surah among the people of Indonesia, while Muhammad Thalib's translation was selected because this translation is the only translation that criticizes al-Qur'an translation carried out by translators team from the Ministry of Religion of Indonesia. This means that Muhammad Talib's translation is better than the Ministry of Religious affairs has.

This research argues that every translation product has shortcomings such as Quranic translation of Muhammad Thalib, even though it is a translation product that criticizes other translation. A translation that seeks to contradict other translations is better than the previous one. The shortcomings are seen from the aspects of the relationship between translation techniques and translation quality.

\section{Literature Review}

This literature review focuses on two main aspects which are translation techniques, and translation quality. The use of certain translation technique significantly affects the quality of the current translation.

\subsection{Translation Technique}

Translation techniques have several theories. Each theory has different translation techniques. However, some translation techniques were unclear until Molina and Albir simplify them. Moreover, these techniques have more clarification from the previous clarification of strategy, procedure, and technique of translation. According to Newmark [17], translation procedures or translation technique are used for sentences and smaller language units, while the translation method is related to the whole texts. Molina and Albir [14], meanwhile, points out that that translation techniques are used to clarify how the resulting translation functions in the source text applied to the corresponding units. In this case, Molina and Albir uses the translation technique as a tool to analyze the result of the translation [14]. 
They add that the category of translation techniques assists researchers identify the concrete steps of the translator in each textual micro-unit and obtain clear data on the general methodological option chosen. Besides, translation techniques are the strategy that has been applied in the translation product. Accurate translation is essential. Making accurate translation can be challenging. The language difference between source language (SL) and target language (TL) is a major factor affecting translation accuracy. Accuracy refers to an accurate understanding of source language messages and converting the message to the target language as accurately as possible.

Translation technique is a tool used to divert messages from SL to TL using terms, phrases, clauses, or sentences. According to Molina and Albir, the techniques of translation have five characteristics; (1) the techniques of translation affect the results of translation; (2) the technique is classified by comparison in the TL text; (3) the technique is at the microlevel; (4) the techniques are not interrelated but based on a specific context; (5) the technique is functional. Molina and Albir propose eighteen (18) translation techniques, namely adaptation, amplification such as explicitation, addition, and paraphrase, borrowing such as pure borrowing and naturalized borrowing, calque, compensation, description, discursive creation, established equivalent, generalization, linguistic amplification, linguistic compression, literal translation, modulation, particularization, reduction such as implication and omission, substitution, transposition, and variation [14].

\subsection{Translation Quality}

It seems difficult to release the discussion about translation products from the aspect of translation quality. There are various ways to assess the quality of translation results such as the Cloze Technique, Reading-Aloud Technique, Knowledge Test, Performance Test, Back Translation, Back-based Approach and Assessment Instruments, such as Accuracy and Readability Rating Instrument [16]. First, The cloze method was developed by Nida and Taber [18]. This approach uses reader level comprehension of target text as a measure of translation accuracy. The reader does so by guessing or anticipating words omitted from a translated text. However, this method has many drawbacks, e.g. (1) it does not calculate how accurately SL messages are transmitted to TL, (2) it does not consider the competence of the target reader, (3) even if guessing can not be used as a guarantee of accuracy. Second, reading aloud technique was also introduced by Nida and Taber [18]. Similar to cloze method, it involves the reader in deciding the translation standard. This method requires the reader to read the translation results and if it is not smooth, the translation is believed to be of low quality. However, the smooth reading does not guarantee a quality of translation. Nevertheless, reading fluency is often linked to psychological factors, so it is difficult to establish a clear connection between reading fluency and translation quality.

Third, knowledge testing techniques is required in order to analyze technical texts. It is achieved by checking the reader's awareness of SL text material. First, TL readers are asked to read a translated text, then answer questions prepared by the assessor. If the reader can answer correctly as many questions as possible, it shows the translated wotk is of high quality [16]. However, Nababan further clarified the limitations of this method, i.e. (1) it is presumed that the reader is allowed to read the translated text when answering questions so that it could not be used as a yardstick to measure of the quality of the translation, (2) it is difficult to compare SL readers and TL readers especially in terms of interpretation; many factors must be involved, such as the competence of each reader and their cultural background. Like knowledge testing, this technique is typically used to determine technical texts' quality. The 
test is performed with the performance of the technician by using the translated text to improve the equipment. The shortcoming of this strategy is in evaluating non-technical texts such as literary works. After that, there is also a chance that the technician is an expert even with poor quality text, he is still able to repair the equipment.

Fourth, back translation as stated by Brislin. For example, the English text (text A) is translated into Indonesian (text $\mathrm{B}$ ) and the translation results are then translated back into English (A'). Text A is then compared to A. If the two texts are the same, the findings will be more reliable. Translation is a creative process, and getting the same results in any translation is hard to find. The results of the translation with the same text may differ with the different translator. In addition, the same text can generate different translated texts when translated by the same translator but executed at different times. This technique is also difficult to use as a translation quality assessment. Fifth, equivalence based approach was introduced by Katharina Reiss. This tehnique uses an equal relationship between SL and TL to assess translation quality. Based on this approach, items to compare are (1) form of text, (2) language characteristics used, (3) extralinguistic factors. Text sort refers to a text's main language feature. Language features apply to semantic, grammatical, and stylistic features. Then, extralinguitic factors refer to the impact on verbalization strategies, different understandings of a text's content, different perceptions of a particular phenomenon [16].

Sixth, accuracy and readibility-rating instrument which was firstly developed by Nagao, Tsuji, and Nakamura and then adapted by Nababan [16]. In implementing this strategy, it uses a scale rating of 1 to 4 : very accurate, accurate, less accurate, and inaccurate. Likewise in the readability assessment, the scale rating is $1-4$; very easy, easy, difficult, and very difficult. The numbers used in this instrument are a number of the tendency to judge a text. The adaptation of calculation numbers was modified by Nababan only to three scales, namely accurate, inaccurate, and inaccurate in the aspect of accuracy; acceptable, less acceptable, and not acceptable on the acceptability aspect, and the readability aspect which is classified into a high, medium, and low readability system. Then, it is known that a translated text can be declared as high quality translation if the text is able to commensurately convey the message. The meaning between the source language and the target language is commensurate in the sense of being appropriate and the message is appropriately conveyed. The messages in SL do not deviate or have the same information. Not only related to meaning, but this equivalence also includes grammatical and pragmatic aspects. Translated text which overemphasize accuracy are usually rigid with grammatical arrangements and often even difficult to understand, whereas it should have a degree of ease to understand and read [16]. To achieve the goal, a good level of readability is needed. The target reader who incidentally does not know the original text can easily understand the text. Even though it is easy to understand, it is possible that readable text cannot convey the message accurately. Therefore, the translated text, in addition to being easy to read, must remain accurate. Acceptability of a text is also known as natural text. An acceptable translated text can be characterized by writing that is no longer like a translated text. The reader may not think that the text is translated text. Acceptability here means that a translation product that is in accordance with the norms, rules and culture of the target language. The work of translation that emphasizes acceptability system can be felt its naturalness in the prevailing grammatical and socio-cultural diction. 


\section{Method}

The present research is a translation study on product translation which is entitled AlQur'an Tarjamah Tafsiriyyah by Muhammad Thalib [24]. It deployed a descriptive qualitative since it described linguistic phenomena in translation techniques and qualities of Surah Yasin in the Qur'an. The data of the study were obtained from the Qur'an Surah Yasin 83 verses and they were analyzed. Data collection techniques utilized content analysis and focus group discussions (FGD). Content analysis was used to obtain the data. FGD which involved raters who are experts in translation studies and Arabic translations was conducted to identify translation techniques and assess translation qualities. The researcher was also involved in FGD. The FGD was used to obtain the objectivity of quality translation assessment. The data from this study was analyzed using two frameworks; translation techniques by Molina and Albir [14] and translation quality assessment (TQA) by Nababan, Nuraeni and Sumardiono [16]. The model of TQA assesses the translation quality holistically as well as the applications for assessing quality translation in the translation research context. There are three aspects in assessing translation quality: accuracy, acceptability, and readability. A good quality translation has to fulfill those aspects.

\section{Findings and Discussion}

\section{1 Translation Technique in Surah Yasin}

Based on FGD results, it was found that Muhammad Thalib's translation techniques were as follows: amplification (paraphrasing) translation technique (27.13\%), established equivalent $(25.99 \%)$, explicitation $(15.5 \%)$, implicitation $(12.8 \%)$, modulation $(8.52 \%)$, compensation $(3.48 \%)$, transposition $(2.32 \%)$ and discursive creation $(1.55 \%)$. The following explanation describes the use of Qur'anic text translation techniques. This study only focuses on techniques that exceeded more than one percent because they are significant to discuss.

Tabel 1: Translation Technique in Surah Yasin

\begin{tabular}{lcc}
\hline \multicolumn{1}{c}{ Translation technique } & Frequency & $\%$ \\
\hline Amplification (paraphrase) & 70 & 27,13 \\
\hline Established equivalent & 67 & 25,99 \\
\hline Amplification (Explicitation) & 40 & 15,5 \\
\hline Implicitation & 33 & 12,8 \\
\hline Modulation & 22 & 8,52 \\
\hline Compensation & 9 & 3,48 \\
\hline Transposition & 6 & 2,32 \\
\hline Discursive creation & 4 & 1,55 \\
\hline
\end{tabular}

\subsubsection{Amplification Technique}

Amplification is a technique of translation that expresses or paraphrases implicit information in the source language. It can be paraphrase, explicitation, and annotation. Paraphrasing techniques are translation techniques that reexpress a concept in the same language in another way, but do not change the meaning. Dhusia \& Kesharwani explains that paraphrasing can be done using several strategies [6]: (1) use different vocabulary words with the same meaning; (2) change the word order pattern; if the sentence consists of two clauses, 
change the order of clauses. If the sentence consists of adjectives and nouns, shift the adjective to a relative clause, (3) use different grammar, i.e. transform the active sentence structure to passive sentences, (4) modify a long sentence to a short sentence, (5) shift numbers and percentages in various ways. Muhammad Thalib uses the techniques for about 27, 13 persentage in translating Surah Yasin. The following is a paraphrasing technique.

Datum 1

\begin{tabular}{|c|c|}
\hline Arabic & 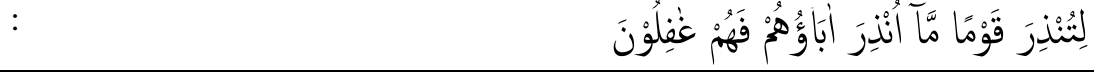 \\
\hline Transliteration & : litunẑira qauman mā unẑira ābāuhum fahum gāfilūn \\
\hline $\begin{array}{l}\text { Yasin } \\
\text { Muhammad } \\
\text { Thalib } \\
\text { (YMT) } 06\end{array}$ & $\begin{array}{l}\text { Wahai Muhammad, Alquran ini untuk engkau gunakan menyampaikan } \\
\text { ancaman kepada kaum Quraisy yang nenek moyang mereka dahulu } \\
\text { belum pernah didatangi Rasul Allah yang menyampaikan ancaman. } \\
\text { Mereka termasuk umat yang tidak mengetahui agama Allah dan tidak } \\
\text { mengindahkan perintah Allah. }\end{array}$ \\
\hline & $\begin{array}{l}\text { 'O Muhammad, this Koran is for you to use to express threats to the } \\
\text { Quraysh whose ancestors had never before been visited by the } \\
\text { Messenger of Allah, who delivered the threat. They have people who } \\
\text { don't know God's religion and do not obey Allah's commands. }\end{array}$ \\
\hline
\end{tabular}

The original text (1) consists of 10 words, namely the words li, tunẑira, qauman, mā, unẑira, ābāuhum, fa, hum, and gāfilūn. The word li means that, tunẑira means you give a warning, qauman means a people, mā means not yet, unẑira means to be warned, ābāuhum means their ancestors, $f a$ means then, hum means them, and gāfilün means negligent people [13]. However, in this verse, Muhammad Talib used the paraphrasing technique to increase the reader's understanding to make the translated version longer. Moreover, the above verse, which originally consisted of one sentence was changed to two sentences by adding some additions.

Table 1: Paraphrase Version

Translated original version $\quad$ Translated paraphrase version

agar engkau memberi peringatan kepada suatu Wahai Muhammad, Alquran ini untuk engkau kaum yang nenek moyangnya belum pernah gunakan menyampaikan ancaman kepada kaum diberi peringatan, karena itu mereka lalai.

Quraisy yang nenek moyang mereka dahulu belum pernah didatangi Rasul Allah yang menyampaikan ancaman. Mereka termasuk umat yang tidak mengetahui agama Allah dan tidak mengindahkan perintah Allah.

That you may warn a people whose forefathers ' $O$ Muhammad, this Koran is for you to warn were not warned, so they are unaware. to the Quraysh people whose forefathers had never before been visited by the Messenger of Allah. They have people who don't know God's religion and do not obey Allah's commands.

Table (1) shows that the paraprase technique was used in adding greetings such as $O$ Muhammad, adding subjects such as the Qur'an, describing objects from the word 'people' to the Quraysh, using the synonym of unaware to be ignorant of being a people who do not know Allah's religion and disregarding Allah's commands. 
Morever, explicitation techniques are translation techniques that explicit vague terms. Holding this technique helps to improve readability or comprehension of the translated text reader. In an Indonesian Dictionary, explicit means straightforward and not complicated. A word that is still unclear, particularly pronouns, is explicitly clarified. Muhammad Thalib also used this technique in the translation of surah Yasin.

Datum 2

\begin{tabular}{lll}
\hline Arabic & $:$ & \\
\hline Transliteration & $:$ & Innaka lamin al-mursalīn \\
\hline YMT03 & $:$ & Sesungguhnya engkau pastilah salah seorang dari rasul-rasul \\
\hline & & Indeed you, are, from among the messengers \\
\hline
\end{tabular}

Datum (2) reveals that Muhammad Thalib explicit the particle is (min) which its original meaning means 'dari' to one of or among due to be followed by the plural word (al-mursalīn) which lexically means the messengers [13].

\subsubsection{Established Equivalent Technique}

Established equivalent techniques are techniques using familiar terms or expressions based on a dictionary or everyday use, or comment from Qur'an commentators. Muhammad Thalib (PMA) used use this technique 67 times which is equivalent to $25.99 \%$. Below is the example of an established equivalent translation technique.

Datum 3

\begin{tabular}{lll}
\hline Arabic & $:$ & \\
\hline Transliteration & $:$ & Ittabi'ū man lā yasalukum ajran \\
\hline YMT21 & $:$ & Ikutilah orang-orang yang tidak meminta upah dari kalian \\
\hline & Follow people who do not call for pay \\
\hline
\end{tabular}

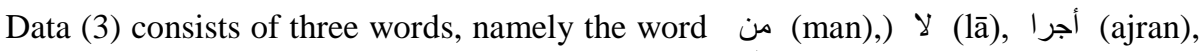

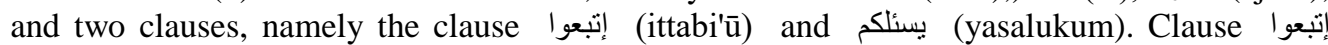
(ittabiū) classified as command verb which functions to govern, من (man) as an ism mausule functions as an object, la is classified as harf nafy which functions to negate something and يسئلكم (yasalukum) which functions as a declarative sentence. Declarative sentence is marked by the use of particles ' $y a$ ' in the word بسئل which signifies its identity as an imperfect verb. When translated into Indonesian, Muhammad Thalib uses established equivalent technique. In the form aspect, the clause إتبعو ا (ittabi'ū) takes the form of a command and its equivalent is in the form of a command too. The form of command could be seen from the use of 'lah' particle at the end of the word 'ikutilah' (follow). In meaning aspect, the word إتبع (ittabi'ū) means follow as imperative sentence, while particles waw and alif at the end of the word refer to the plural pronoun أنتم (antum) which means you. This word is used instead of the previous word يسئلكم (qaum) in the previous verse. Likewise, the word ن من (man), ل (lā) and (yasalukum) when translated in Indonesia use contextual meaning and based on the dictionary, like by 'people, no, and asks you' [13].

In this context, this verse talks about the story of a man who hurried to come from a distant city and said, "who does not ask for your reward" and then the sentence, "they're the 
ones who're driven." This sentence reflect the people's view on that era. They saw everyone like themselves. Deprived people demanded compensation from other and they were known for this attitude. They knew hardly the authenticity of their actions and therefore did not believe that the apostles were genuine and requested compensation for their demands. Because it is something ingrained in the population's soul, it is natural to be denied first, so the man who rushed overtakes him. On the other hand, in refusing the demand for compensation, the aforementioned verse uses the present verb together (yasalukum) in the form of verbal sentences as a sign that even if they never ask for it, let alone repeatedly and become their intent, the form used is nominal sentences hum muhtadun to suggest their intention.

\subsubsection{Implicitation Technique}

Implicitation translation techniques are techniques that suggest specific details in the target language text in the source language. This can be seen in the cases below.

Datum 4

\begin{tabular}{lll}
\hline Arabic & $:$ & \\
\hline Transliteration & $:$ & Wa ja'alnā... \\
\hline YMT09 & $:$....Orang-orang kafir... \\
\hline & ...The infidels \\
\hline
\end{tabular}

Above datum (4) reveals that the word waw is not translated into the target language in the source language. The term waw as waw al-atf is translated with the word 'and' but in the above translation, the word 'and' is implied so that it specifically refers to the topic of paraphrased, 'infidels [13].

\subsubsection{Modulation Technique}

Modulation is a translation technique where the translator changes the viewpoint, focus, or cognitive categories of the source language. Changes can occur in grammatical and lexical forms. Newmark [17] also shared the same regarding modulation as Molina \& Albir. The following examples illustrate this.

Datum 5

\begin{tabular}{lll}
\hline Arabic & $:$ & \\
\hline Transliteration & $:$ & Aattakhiżu min dūnihī ālihatan \\
\hline YMT23 & $:$ Apakah aku patut menyembah tuhan-tuhan selain Allah \\
\hline & Am I worthy of worshiping gods besides Allah \\
\hline
\end{tabular}

The above verse consists of six (6) words, namely the words أ (a), أتخذ (attakhiżu), من (min), دون (dūni), • (hī), and الهة (âajat). The word أ (a) means whether, أتخذ (attakhiżu) means I will make, دن (dūni) means other than, o(hī) means it, and الهنة (2) means of (āajat) means God- God [13]. If translated verbatim, the above verse means, 'will I make it from other than Gods.' This kind of translation makes it difficult for the reader to understand the meaning. Therefore, Muhammad Thalib changed the perspective of the above translation by changing the clause 'I will make it' into worthy of worship. This modulation translation technique occurs lexically. 


\subsubsection{Compensation Technique}

Compensation technique is a translation technique that transfers messages to other parts of the translated text. It also means that the translator introduces information elements or the stylistic influence of the source language text elsewhere in the target language text. In the Qur'an it is stated that وامتازوا اليوم أيها المجرمون (wa imtāzū al-yauma ayyuhā al-mujrimūn) which means "and (said to unbelievers)," Separate you (from the believers) on this day, sinners! [13] " translated as "O people who sin, today you separate from the believers." Lexically, the phrase ' $O$ sinners' lies at the end of the verse (sentence), but when translated into the target language, the phrase is placed in front of the phrase. This technique is done to improve the readability of the text to assist readers' understanding.

\subsubsection{Transposition Technique}

Transposition techniques are the techniques that substitute target language structural order. Newmark [17] conveys this process, naming it shifts or transposition. In A Linguistic Theory of Translation, Catford [28] classifies translation shifts into two forms, level shift, and category shift. The level shift is the grammatical-level translation shift to a lexical level in the target language. For example, 'he's fasting' means 'Dia sedang berpuasa.' In Indonesian, the grammatical structure to be + Ving lexically changes to the word 'sedang'. The class shift is a translation change that happens due to the free translation process, so it does not focus on the grammar equivalent of the source language and target language. This kind of translation is considered good as it generates appropriate translatin in the target language. Category shift classifies into a class shift, structure shift, unit shift, and intra-system shift. The following is a transposition technique example.

\begin{tabular}{|c|c|}
\hline \\
\hline Arabic & 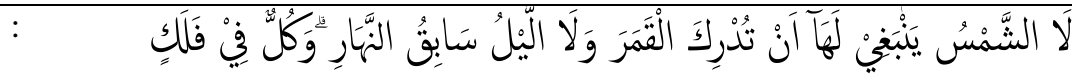 \\
\hline Transliteration & $\begin{array}{l}\text { Lā asy-syamsu yanbagī lahā an tudrika al-qamara wa lā al-lail sābiq an- } \\
\text { nahār wa kullun fĩ falakin yasbaḥun }\end{array}$ \\
\hline YMT40 & $\begin{array}{l}\text { Matahari tidaklah mendahului bulan. Malam tidaklah mendahului siang. } \\
\text { Masing-masing beredar pada garis edarnya. }\end{array}$ \\
\hline & $\begin{array}{l}\text { The sun does not reach the moon. The night does not precede the day. } \\
\text { Each, in an orbit, is swimming. }\end{array}$ \\
\hline
\end{tabular}

Datum (6) consists of only one verse. One verse in Arabic is one sentence. When translated, this verse changes into several Indonesian sentences. This can be seen from YMT 40 translated text using three sentences. In the first sentence, the sun does not reach the moon. In the second sentence, the night does not precede the day. The third sentence, each, in an orbit, is swimming. Therefore, a unit change occurred from one sentence to three sentences.

\subsubsection{Discursive Creation}

Discursive creation is the translation technique of using a transient or unpredictable counterpart. In other words, translation techniques that aim to establish a temporary equivalent outside the context [14]. 
Datum 7

\begin{tabular}{|c|c|c|}
\hline Arabic & : & 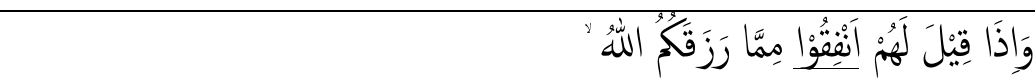 \\
\hline Transliteration & : & Wa iẓā qīla lahum anfiqū mimmā razaqakumullah \\
\hline YMT47 & $:$ & $\begin{array}{l}\text { Bila ada yang berkata kepada mereka: "Dermakanlah untuk membela } \\
\text { Islam sebagian dari rezeki yang Allah karuniakan kepada kalian }\end{array}$ \\
\hline & & $\begin{array}{l}\text { If anyone says to them: "Give to defend Islam in part of the sustenance } \\
\text { that Allah has given to you }\end{array}$ \\
\hline
\end{tabular}

In this context, this verse tells the tale of one of the Meccan Musyrik's reluctant to support poor Muslim groups [3]. It was because of, Abu Jahal met Abu Bakr who was feeding the poor. He also asked Abu Bakr, "Is Allah able to feed the poor man?" Abu Bakr responded, "Yes." Abu Jahl chimed in, "Why didn't Allah feed them?" Abu Bakr replied, "Allah tested poor people and tested a wealthy people. God commands the needy to be patient and commands the rich to give. Abu Jahal also said," By Allah, Abu Bakr, You are truly a lost person. If Allah can feed these poor people, why should Allah not feed them, because you are the one who feeds them. Moreover, this verse is in line with previous verses telling about the character of the Mushrik Quraysh who, in addition to rejecting the Prophet's call to receive the Qur'an revelation, also refused to reveal one God. Textually, the clause (anfiqū), in the Lisān Al-Arab Dictionary, means contributing Allah's way, eating, and giving alms [13]. Accordingly, scholars of classical and contemporary Qur'anic interpretations, such as AtTabarī [4] and Ash-Shiddieqy [3] give the same meaning to the clause (anfiqū) as 'donate'

Muhammad Thalib translated the clause (anfiqū) by donating for the defense of Islam. In-text and context, Arabic linguists and commentators interpret the term (anfiqū) as donates. However, adding phrases to defend Islam is inappropriate and out of the context. In the Indonesian Dictionary (KBBI), the term 'defend' means taking sides to protect and defend. If the term 'defend' juxtaposed with the word 'Islam', it means taking sides to protect and defend Islam. This also means that in the interest of his religious ideology, Muhammad Thalib tries to build the above verse to uphold Khilafah Islamiyyah in Indonesia. This verse was revealed to call on polytheists to offer their resources to support those in need while adding phrases to defend Islam is meant to spend a property to defend Islam. It is two different things. It seems the Muhammad Thalib did not try to translate the above verse but interpreted the verse following its ideological interests.

\section{1 The Effect of translation technique to translation quality in Surah Yasin}

Translation technique is undeniably has a strong association with translation quality. Molina \& Albir state that translation techniques can influence message accuracy, acceptability, and readability [14]. FGD findings showed that Muhammad Thalib used discursive creation translation techniques that significantly affected the message's accuracy. Discursive creation techniques reduce the accucary of translation and allow average translation accuracy at just 2.93. However, translation techniques also affect the message's acceptability and readibility. In this case, the use of pure borrowing techniques decreases the acceptability and readability of the translated text. The average of the acceptability and readability of translated text reachs 2.98. Overall, Muhammad Talib's translated texts average quality reachs 2.96. This indicates that the tendency of Muhammad Thalib's translation particularly for surah Yasin are very good even though there are deficiencies in the accuracy aspect using discursive creation techniques and the deficiencies in the acceptability and readibility aspects because of using pure borrowing techniques. 


\section{Discussion}

The findings of this research suggest that the paraphrase technique is dominant in this research. This paraphrasing technique is used to further elaborate on the Qur'an verses that the reader can not understand well. Muhammad Talib stated that there are 3229 verses need to be amended from the translated text of the Qur'an made by the translator team from the Ministry of religious affairs of Indonesia [24]. The paraphrase used in this study is different from what was suggested by the experts. Paraphrasing usually makes sentences of target text shorter, but in this analysis, the paraphrased texts are longer. This technique is indeed paralleled with his idea of Tarjamah Tafsiriyyah. Tarjamah tafsiriyyah is a translation concept based on expert commentators' interpretation. Becuase it is based on the experts' commentators, this translated text automatically becomes longer than the source-language text [25].

Morever, the use of paraphrases technique have several weaknesses. This technique has distorted the Qur'anic verse's original meaning itself. This technique has become a means to insert the translator's ideas in the target text due to its paraphrase. Muhammad Thalib's translation is basically the concept of creating the Khilafah Islamiyyah state in Indonesia [11]. Nida stressed that paraphrasing techniques made translated texts extremely arbitrary [14]) and easily manipulated. In the paraphrase tehcnique, the sentences become longer. Then, the technique of discursive creation is inserted in one ar two words or phrases. The use of discursive creation certainly affects aspects of accuracy because the source language meaning has changed. This implies that translation and commentary of the Qur'an are different. Translation is to convey source language messages into the target language in both form and meaning. Meanwhile, commentary is expert's interpretation of the text of the Qur'an according to their background and approach used. In addition, this study implies that the translation of the text of the Koran can be manipulated by anyone with an interest. It can be traced through the use of discursive creation techniques in his or her translation products. In line with Muhammad Thalib, Robert Ketton also used to translate the Qur'an from Arabic to Latin in the early XI century [5]. He also used paraphrase techniques based on the interpretation of the commentators like At-Tabari and As-Suyuti as Muhammad Thalib did. It is just that, in the translation which later became the reference material for translators such as Albery, the translated text contains the concepts and ideas of translators, such as the concept of orientalism that is included in the text of his translated Qur'an.

\section{Conclusion}

The use of paraphrasing techniques was not only carried out by Muhammad Talib, but also by Robert Ketton in translating the Qur'an from Arabic into English. The paraphrasing translation techniques also offer incentives and resources for translators to integrate basic principles of thought into the translated text. If Robert Ketton included the concept of orientalism in his translated text, Muhammad Thalib included the concept of Khilafah Islamiyyah thought in his translated text of the Koran. The inclusion of these principles resulting in the inaccuracy of the original message. All of this can be learned by the reconstruction of the translator's thought through translation techniques.

The translation technique used by Muhammad Talib in his Quranic translation texts are as follows; paraphrasing translation technique (27.13\%), established equivalent (25.99\%), explicitation $(15.5 \%)$, implicitation $(12.8 \%)$, modulation $(8.52 \%)$, compensation $(3.48 \%)$, transposition $(2.32 \%)$ and discursive creation $(1.55 \%)$. This result suggests that the paraphrase 
translation technique is the most dominant translation technique. Meanwhile, the use of discursive techniques make the accuracy of the message reduced. Besides, elements of message acceptability and readability often get low marks due to the use of pure borrowing techniques. It can be concluded that the translation of Muhammad Talib's Quran is very good with an average value of 2.96 out of the total overall value of 3 while it has some shortcomings in many aspects.

This research has many limitations. The limitation lies in the data sample which is only confined to one of the surahs in the Koran so that it has not yet provided a thorough understanding of how the effect of translation techniques on the quality of translation. Therefore, future work should be carried out with a wider sample of research data to provide an in-depth of the impact of translation techniques on the quality of translation.

\section{References}

[1] Ahmadi, R. Model Terjemahan Al-Qur'an Tafsiriyah Ustad Muhammad Thalib. Jurnal CMES. 2015. 8(1), 57-69.

[2] Annisaa, I., Nababan, M. R., \& Djatmika, D. Analisis Kualitas Keterbacaan Pada Quran Surat AlKahfi Ayat 1-10 Dalam Dua Versi Terjemahan (Depag Ri Dan Mmi). KoPeN: Konferensi Pendidikan Nasional. 2020. 2(1), 131-136.

[3] Ash-Shiddieqy, T. M. H. Tafsir Al-Qur'ānul Majid An-Nuur, Vol. 4. Semarang: Pustaka Rizki Putra. 2000.

[4] At-Tabarī, M. ibn J. ibn Y. ibn K. ibn G. A. J. Jāmi' al-Bayān fì Ta'wīl al-Qur'ān. al-Qāhirah: Muassasah ar-Risālah. 2000.

[5] Burman, T. E. Tafsīr and Translation: Traditional Arabic Qur'ān Exegesis and the Latin Qur'āns of Robert of Ketton and Mark of Toledo. Speculum. 1998. 73(3), 703-732.

[6] Dhusia, D. K., \& Kesharwani, S. Strategy for writing Plagiarism free Research Paper. Global Journal of Enterprise Information System. 2019. 11(2), 90-96.

[7] Farisi, M. Z. A. Analisis Terjemahan Ayat-Ayat Imperatif Alquran (Telaah Komparatif Terjemah Depag Dan Terjemah Umt) (Doctoral dissertation, Universitas Pendidikan Indonesia), 2016.

[8] Faza, A. M. Reading Surah Yasin At Night: Study of Takhrij al-Hadits. Jurnal Ushuluddin. 2016. 24(1), 20-36.

[9] Gunawan, F. The Effect of Translation Technique to Its Quality at The Holy Book of Indonesian Moslem Society. 2019. Lisan: Jurnal Bahasa dan Linguistik, 8(2), 101-109.

[10] Istianah, I. Dinamika Penerjemahan Al-Qur'an: Polemik Karya Terjemah Al-Qur'an HB Jassin dan Tarjamah Tafsiriyah Al-Qur'an Muhammad Thalib. 2016. Maghza: Jurnal Ilmu Al-Qur'an dan Tafsir, 1(1), 41-56.

[11] Kurniawan, A., \& Aminuddin, A. Muhammad Thalib, Majelis Mujahidin Indonesia, Dan Tafsir Ayat-Ayat Penegakan Syariat Islam Di Indonesia. Teosofi: Jurnal Tasawuf dan Pemikiran Islam. 2018. 8(1), 113-143.

[12] Mansoori, M., \& Afshari, M. The comparative analysis the modal verbs in three Surahs:" Yasin, Al-Rahman and Yusuf" and their contrastive Persian and English translations. International Journal of Medical Research \& Health Sciences. 2016. 5(9), 178-183.

[13] Manzūr, I. (1955). Lisān al-A 'rab. al-Qāhirah: Dār al-Ma'ārif.

[14] Molina, L., \& Albir, A. H. Translation techniques revisited: A dynamic and functionalist approach. Meta: Journal Des Traducteurs/Meta: Translators' Journal. 2002. 47(4), 498-512.

[15] Muhammad, M. Dinamika Terjemah Al-Qur'an (Studi Perbandingan Terjemah Al-Qur'an Kemenerian Agama RI dan Muhammad Thalib). Jurnal Studi Ilmu-ilmu Al-Qur'an dan Hadis. 2018. 17(1), 1-24.

[16] Nababan, M., Sumardiono \& Nuraeni, A. Pengembangan Model Penilaian Kualitas Terjemahan”. Jurnal Kajian Linguistik dan Sastra. 2012. 24(1).

[17] Newmark, P. A Textbook of Translation. New York: Prentice Hall Inc. 1988.

[18] Nida, Eugene A \& Taber, Charles R. The theory and practice of translation. Brill Archive.1969 
[19] Nurdin, N., \& Puteri, N. B. Perbandingan Metode Transformasi Wavelet Dan Fourier Dalam Penterjemahan Ayat Pada Surah Yasin. Sistemasi: Jurnal Sistem Informasi. 2020. 9(1), 16-26.

[20] Ridho, M. A., Arini, A., \& La Katjong, B. Aplikasi Multimedia Terjemahan Surah Yasin Dalam Bahasa Jawa Menggunakan Bahasa Pemrograman Lingo. Jurnal Online Informatika. 2016. 1(2), 70-75.

[21] Rohani, W., \& Mokhtar, W. Penggunaan uslub khabari dalam Al-Quran: Kajian terhadap Surah Yasin (Doctoral dissertation, University of Malaya). 2012.

[22] Rum, I. M. Fenomena Alih Bahasa Al-Qur'an: Kritik atas Koreksi Muhammad Thalib Terhadap Terjemah Kemenag RI. Suhuf: Jurnal Pengkajian Al-Qur'an dan Budaya. 2015. 8(2), 203-232.

[23] Rusydi, A. Seluk Beluk Surah Yasin: Kajian Tafsir Maudlu'i. Al-Risalah. 2019. 15(2), 131-154.

[24] Thalib, A.-U. M. Al-Qur'anul Karim Tarjamah Tafsiriyyah. Solo: CV Qolam Mas. 2012.

[25] Thalib, M. Koreksi Tarjamah Harfiyah Al-Qur'an Kemenag RI: Tinjauan Aqidah, Syariah, Mu'amalah, Iqtishadiyah. Yogyakarta: Ma'had An-Nabawy. 2011.

[26] Ubaidillah, U. Al-Dakhiliyah 'Ala Al-Asma': Dirasah Tahliliyah Nahwiyah Fi Surah Yasin. LiNGUA: Jurnal Ilmu Bahasa dan Sastra. 2018. 13(1), 60-68.

[27] Yahya, M. Peneguhan Identitas dan Ideologi Majelis Mujahidin Melalui Terjemah Al-Qur'an. Religia. 2018. 21(1), 188-208.

[28] Catford, J. C. A Linguistic Theory of Translation; an Essay in Applied Linguistics: By JC Catford. Oxford UP. 1965 